Збірник наукових пращь Державного науково-дослідного інституту випробувань і сертифікачї̈ озброєння та військової техніки. 2019. Вип. № 2

ISSN 2706-7386

УДК 629.7.018.77

DOI: $10.37701 /$ dndivsovt.2.2019.14

Кульба П.П., Лампік М.М., Бурсала О.О. Державний науково-дослідний інститут випробувань і сертифікації озброєння та військової техніки

\title{
ОБГРУНТУВАННЯ ДОЦЛЬНОСТІ ТА БЕЗПЕКИ ПІДГОТОВКИ ЛЬОТНОГО СКЛАДУ ВИКОНАННЮ ПОЛЬОТІВ НА ДОСЛІДЖЕННЯ ШТОПОРУ ТА ЇХ ВПРОВАДЖЕННЯ У БОЙОВУ ПІДГОТОВКУ
}

Розглянута актуальна проблема відсутності у льотного складу навичок пілотування літака в складних просторових положеннях. Надані рекомендації щчодо внесення змін до курсу бойової підготовки, виконання випробувальних польотів на дослідження штопору на літаку Л-39М1.

Ключові слова: складне просторове положення, звалювання, штопор, бойова підготовка, маневровий повітряний бій, безпека польотів, за критичний кут атаки.

Постановка проблеми. За останні п’ять років в авіації Збройних Сил України трапилось вісім авіаційних подій: шість катастроф та дві аварії, з них шість - в авіації Повітряних Сил Збройних Сил України, дві - в армійській авіації Сухопутних військ Збройних Сил України. Причиною всіх авіаційних подій став людський фактор. Незважаючи на заходи, які вживаються керівним складом Міністерства оборони України та Збройних Сил України для забезпечення безпеки польотів на прийнятному рівні, виконання польотів без аварій та катастроф з причини людського фактору, збереження життя і здоров'я всіх категорій авіаційних фахівців та авіаційної техніки, в авіації Збройних Сил України продовжують мати місце авіаційні події із загибеллю особового складу. Зокрема, катастрофи Л-39M1 29 вересня 2017 року, та Су-27С 15 грудня 2018 року пов'язані з потраплянням літака в складне просторове положення та недостатньою підготовкою льотчиків до польотів на таких режимах.

У наш час теорія штопора досконально вивчена, однак цей режим польоту час від часу, через невміння його розпізнати, призводить до нових жертв.

Аналіз останніх досліджень і публікацій, мета, постановка завдання. Слід зазначити, що незважаючи на великий обсяг теоретичних і експериментальних досліджень впродовж майже століття [1]-[5], проблеми звалювання та штопора і сьогодні актуальні для сучасної авіації і полягають у відсутності у льотного складу навичок пілотування літака в складних просторових положеннях. У деяких випадках, при грубих помилках у пілотуванні, внаслідок взаємодії різних видів руху можуть виникати небезпечні режими польоту.

Метою даної роботи є докладний розгляд причин виникнення критичних режимів звалювання і штопору, вивчення порядку дій по виведенню з них і надання рекомендацій щодо навчання льотчиків (курсантів) за допомогою спеціально навченого інструкторського складу виконанню випробувальних польотів на дослідження штопору на літаку Л-39M1, і 3 цією метою внесення відповідних доповнень до курсу бойової підготовки.

Викладення основного матеріалу. У перші роки розвитку авіації потрапляння літака в складне просторове положення, як правило, закінчувалося катастрофою. Однак, про існування таких сугубо специфічних режимів польоту, як звалювання і штопор, тоді не підозрювали. Велику кількість аварій i катастроф пояснювали потраплянням літака в повітряні вихори і помилками льотчиків, хоча насправді (як виявилось пізніше) причиною аварій було звалювання з подальшим входом у штопор. 
В 1916 році льотчик К.К. Арцеулов уперше навмисно ввів літак у штопор і успішно вивів 3 нього. Запропонований ним метод виводу з штопору був включений до програми льотного навчання і широко застосовувався в льотній практиці.

У роки, коли в льотних училищах фундаментально освоювали штопор, число льотних подій через випадкове потрапляння у цей режим було відносно невеликим, та й пілоти почували себе впевнено в маневреному повітряному бою. Перед війною, враховуючи суворість літаків того часу в пілотуванні, навчання льотчиків штопору на У-2 і УТ-2 було обов'язковим. Курс льотної підготовки передбачав його виконання у самостійних польотах курсантів на бойових машинах И-16 [3].

Літаки часів Другої світової війни конструкції Яковлєва й Лавочкіна, порівняно 3 довоєнними типами, мали більш сприятливі характеристики виведення з критичних режимів. Однак, виконання штопора при перевірці техніки пілотування на спарках “Як” і “Ла" залишалося обов'язковим.

Наприкінці 40-х років на озброєння стали надходити реактивні винищувачі. Найбільш масовий з них, МиГ-15, принципових особливостей на виводі зі звалювання і штопора в порівнянні з поршневими попередниками не мав. Правда, на ньому, як на УТ-2 і И-16, відзначався вплив відхилених елеронів на характер обертання. Цікавий і той факт, що в 1952 році, будучи ще льотчиком-випробувачем НДІ ВПС, космонавт Г. Береговий навчав штопору пілотів двох військових округів, про що потім зробив доповідь. Жодної передумови до льотної події у нього в той період не було. Інші свідчення також дають підставу стверджувати: на літаках із задовільними характеристиками стійкості й керованості освоєння штопора не представляє особливої небезпеки, хоча й вимагає спеціальної підготовки інструкторського складу. Проте, думка про підвищену аварійність при цьому стала однією із причин, яка поклала початок негативному відношенню до освоєння критичних режимів. Навчання штопору, що проводилося надалі в льотних училищах, зводилося до виконання 3 горизонтального польоту одного спадного витка на навчальному літаку Л-39, не можна було сприймати серйозно. Однак нині й воно заборонено.

У радянській авіації, якийсь час, штопору навчалися всі льотчики стройових частин i курсанти льотних училищ, але незабаром за наказом головнокомандувача ВПС це було заборонено. Ухвалене рішення пояснювалося тим, що, за суб'єктивною думкою командування, при відпрацьовуванні штопора було загублено літаків більше, ніж в авіаційних частинах у звичайних польотах.

Стаття полковника М.Раєвського “Обучать ли штопору?” (“Авиация и космонавтика”, 1990, № 3), у якій мова йшла про заборону навчання штопору на літаку Л-39 курсантів льотних училищ і негативні наслідки цього кроку, ще в ті часи описувала ситуацію, що склалася на даний момент. Становить інтерес історія появи даної проблеми. Відношення до навчання критичним режимам польоту у різний час було неоднозначним. Воно грунтувалося не тільки на суб'єктивних поглядах окремих особистостей, але й на складних концепціях застосування ВПС.

Автори статті мали доступ до статистики аварійності серійних літаків й намагалися знайти документальне підтвердження думці “у верхах”, яка спричинила заборону навчанню штопору, однак безрезультатно.

Звалювання і штопор відносяться до критичних режимів польоту, які відбуваються на кутах атаки, більших за допустимі (Рисунок 1). 


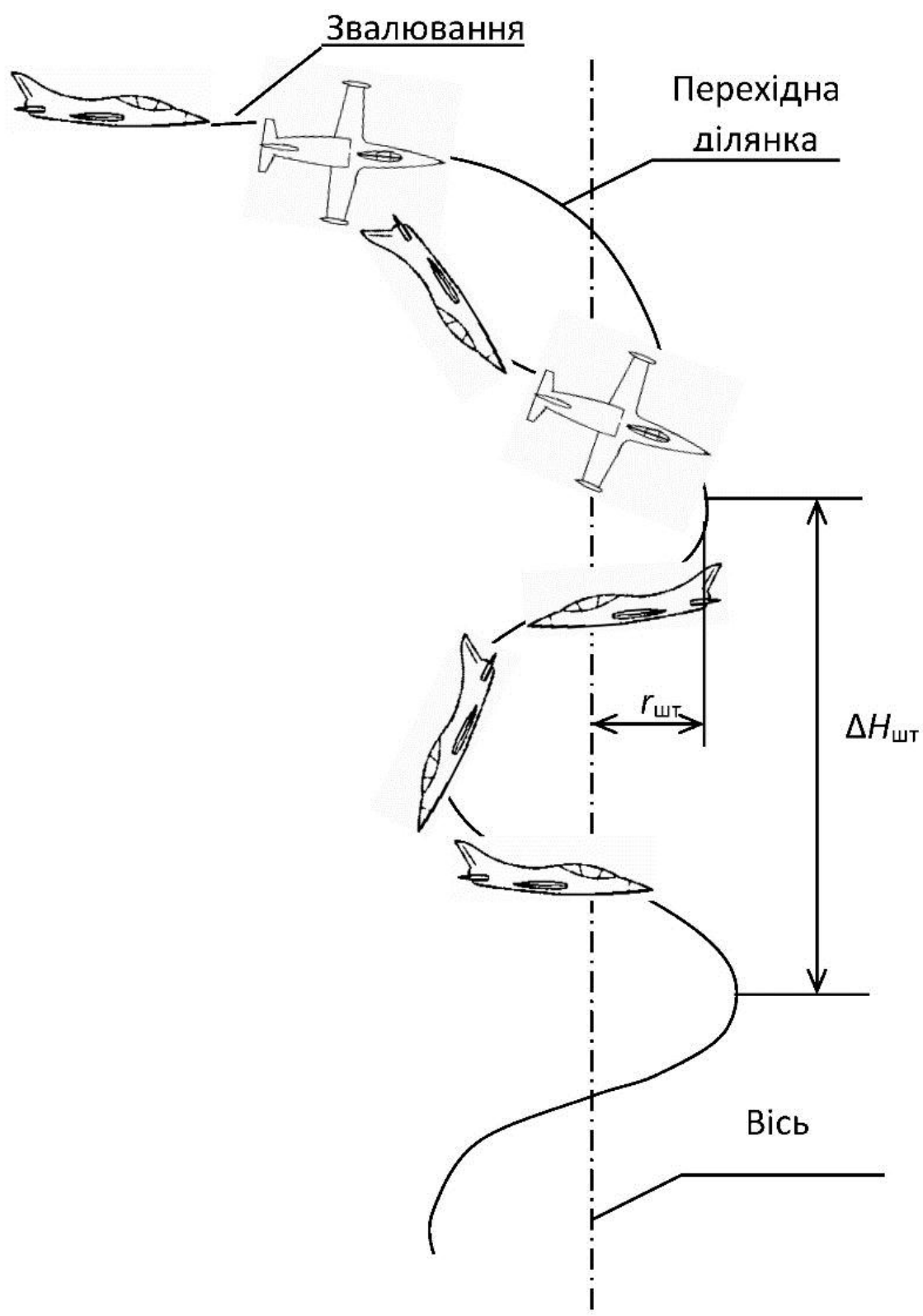

Рисунок 1 - Рух літака при звалюванні і в штопорі

Звалювання - це критичний режим польоту, що відбувається на кутах атаки, більших

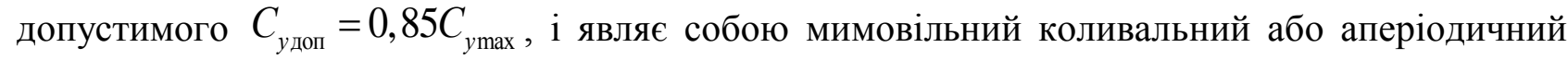
рух літака відносно будь-якої осі з порівняно великими кутовими швидкостями, помітними для льотчика середньої кваліфікації. Звалювання відбувається неочікувано для льотчика, і $\epsilon$ небезпечним, так як супроводжується втратою керованості і не парирується звичайними методами пілотування без зменшення кута атаки. При цьому характерною помилкою льотчика $є$ взяття ручки управління на себе $з$ намаганням уникнути опускання носу літака.

Види звалювання:

а) на ніс (такий вид звалювання виникає на літаку Л-39);

б) $з$ просторовим аперіодичним рухом:

- на крило;

- 3 інтенсивним кабрируванням;

- $з$ різким розворотом по курсу;

в) коливальне;

г) глибоке.

За початковими умовами усі режими звалювання розділяються на три групи:

а) звалювання з мінімальної швидкості прямолінійного горизонтального польоту; 
Збірник наукових праць Державного науково-дослідного інституту випробувань і сертифікацї озброєння та військової техніки. 2019. Вип. № 2

б) звалювання з координованого (без ковзання) вертикального маневру;

в) звалювання $з$ довільного просторового маневру.

Звалювання - це фактично початковий крок штопору. Цей режим польоту не $\epsilon$ фігурою пілотажу й підтримується моментом авторотації (самообертання) крила.

Суть моменту авторотації описується в [1] і полягає в тому, що на відміну від появи демпфіруючого моменту на докритичних кутах атаки, на закритичних кутах атаки різниця коефіцієнтів підйомної сили на різних напівкрилах призводить до появи моменту, що підсилює обертання літака до певного значення кутової швидкості, яке відповідає усталеній швидкості авторотації.

Саме це явище підтримує обертання літака під час штопора.

Початкова стадія зриву в штопор (звалювання) виглядає так:

опускається капот з одночасним креном переважно праворуч і якщо льотчик одразу не зрозуміє, що відбувається й почне виправляти крен відхиленням ручки у зворотній бік й на себе, намагаючись усунути опускання носу літака, то будуть створені всі умови для енергійного переходу літака в штопор.

Ознаками початку звалювання є:

- мимовільне збільшення крену й опускання носу літака з кутовою швидкістю приблизно 0,1 рад/с;

- створюється враження, що вас закручує у вир.

Як цього не допустити?

Правильні дії при звалюванні:

Енергійно поставити рулі у нейтральне положення.

Літак виконає кивок із втратою висоти декількох десятків метрів і через 2...3 секунди керованість повністю відновиться.

Але, якщо льотчик своєчасно не розпізнає початок зриву, то через $2 . . .3$ секунди буде пізно. Літак енергійно перейде в штопор, а для виводу будуть потрібні сотні метрів, яких на четвертому розвороті може й не бути.

Штопор - це некерований рух літака за спіральною низхідною траєкторією малого радіусу з одночасним обертанням відносно всіх трьох осей на закритичних кутах атаки, який супроводжується частковою або повною втратою керованості. Основною причиною штопору $\epsilon$ вихід на закритичні кути атаки, отже, основним завданням для виходу з штопору $\epsilon$ зменшення кутів атаки до докритичних значень.

Штопор на літаку Л-39 більшою мірою носить керований характер через відносно невелику масову щільність, яка не дає йому без відхилення руля висоти на себе створити

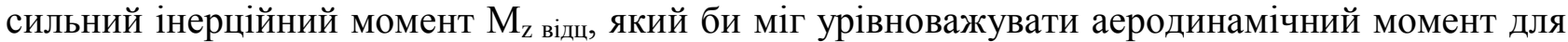
підтримання літака на закритичних кутах атаки. Тому, для витримування умов штопору літака Л-39 льотчику необхідно відхиляти руль висоти на себе для створення додаткового дестабілізуючого моменту, який в сукупності 3 інерційним моментом урівноважує стабілізуючий аеродинамічний момент, який направлений на зменшення кута атаки.

Основні параметри штопору розглядають для сталого режиму, коли вісь штопора наближається до вертикалі, а значення таких параметрів руху, як поступальна швидкість, кут атаки, кут ковзання, кутова швидкість обертання $(V, \alpha, \beta, \omega-$ відповідно) можна вважати постійними.

До основних параметрів штопора відносять:

- нормальне перевантаження у центрі мас літака:

$$
n_{y a}=\frac{1}{\sin \alpha}
$$


- швидкість руху літака у сталому режимі штопора:

$$
V_{\text {шт }}=\sqrt{\frac{2 m g}{C_{y a_{\max }} \rho_{\infty} S} \cdot \frac{1}{\sin \alpha}} \quad \text { або } \quad V_{\text {шт }}=V_{\min _{\Gamma \Pi}} \sqrt{n_{y_{a}}},
$$

де $V_{\min }=\sqrt{\frac{2 m g}{C_{y a \max } \rho_{\infty} S}}$ - мінімальна швидкість, що визначається 3 умови виконання горизонтального польоту $Y_{a}=m g$, коли підйомна сила дорівнює силі ваги літака;

в свою чергу, $C_{y a_{\max }}$ - максимальний коефіцієнт підйомної сили, що відповідає початку звалювання; S - характерна площа і $\rho_{\infty}$ - густина повітря;

- радіус кривизни траєкторії у горизонтальній площині:

$$
r_{\text {гор }}=\frac{g}{\omega^{2} \operatorname{tg} \alpha} ;
$$

- час одного витка:

$$
t_{\mathrm{B}}=\frac{2 \pi}{\omega}
$$

- втрата висоти за виток:

$$
\Delta \mathrm{H}_{\text {шт }}=V_{\text {шт }} t_{\mathrm{B}} .
$$

Для Л-39 кутова частота обертання у сталому штопорі змінюється від $+3,5$ до $-2 \mathrm{c}^{-1}$, час одного витка складає $6 . .7 \mathrm{c}$, швидкість руху $V_{\text {Шт }}=60 \ldots 200 \mathrm{M} / \mathrm{c}$, втрата висоти за виток $\Delta H_{\text {шт }}=300 \ldots 400$ м, загальна втрата висоти від моменту введення до штопору до виводу в горизонтальний політ за умови виконання одного витка штопора складає 500-650 м.

Основна причина штопора - це політ на великих кутах атаки, тому для виведення зі штопору необхідно зменшити кут атаки, тобто змінити положення осі обертання. Це вимагає від льотчика знань для визначення поведінки літака при потраплянні у критичний режим та практичних навичок щодо відхилення органів керування з метою виведення з цих режимів.

У світовій практиці шляхи вирішення цієї проблеми обговорюються давно, в період 3 2001 по 2011 рік льотні події з літаками, обумовлені втратою керованості в польоті (LOC-I), були головною причиною катастроф у цивільній авіації. Льотні події типу LOC-I часто призводять до катастрофічних наслідків, причому живими залишаються лише одиниці, якщо взагалі залишаються.

Після Конференції в червні 2009 року, яка була присвячена проблемам потрапляння літаків у складні просторові положення й втрати керованості в польоті (LOC-I), Королівське суспільство аеронавтики (RAeS) ініціювало дослідження причин LOC-I i підготовку рекомендацій із запобігання подібних подій, зокрема, шляхом можливих поліпшень міжнародних стандартів в області цивільної авіації й відповідних інструктивних матеріалів. Ця робота була почата Міжнародним комітетом Королівського суспільства аеронавтики (RAeS) 3 авіаційної підготовки і навчанню в розширених областях робочих режимів (ICATEE), а IКАО підтримала цю ініціативу [5].

У 2011 році Федеральне авіаційне управління (ФАУ) Сполучених Штатів Америки заснувало Авіаційний комітет з розробки правил (ARC) для розробки ефективних методик підготовки льотних екіпажів до вміння запобігати потраплянню літаків у складні просторові положення (СПП) і виводу з них. В 2012 році ІКАО, Європейське агентство по безпеці польотів (САБП) і ФАУ вирішили об'єднати свої зусилля з метою ідентифікації й визначення прийнятного підходу до зниження ймовірності виникнень подібних подій. В 2012 році ІКАО організувала проведення семи нарад, у ході яких представникам відомств цивільної авіації (ВЦА), а також ARC ФАУ й експертам 3 даної тематики пропонувалося взяти участь у 
цільових дискусіях. Крім того, оскільки декілька ініціатив, пов'язаних зі зменшенням числа випадків втрати керованості в польоті (LOC-I), здійснювалися одночасно, IКАО запросила багато груп фахівців, залучених до цих ініціатив, взяти участь у наступних обговореннях цієї теми, яка стала відома як ініціатива 3 підготовки запобігання втрати керованості й виходу 3 такого положення (LOCART).

Зменшення кількості льотних подій типу LOC-I давно стало пріоритетом для IKAO, у зв'язку з чим IКАО розробила гармонізовані вимоги до підготовки льотних екіпажів, які спрямовані на зменшення числа інцидентів, пов'язаних із втратою керованості в польоті (LOC-I). За рекомендаціями ICATEE i ARC ФAУ IKAO внесла покращення в діючі Стандарти й Рекомендовану практику (SARPS), а також у відповідний інструктивний матеріал. Вимоги до навчання на повітряному судні на рівні підготовки пілотів комерційної авіації й пілотів багаточленних екіпажів, а також підготовки на тренажерах імітації польоту на рівні лінійних пілотів авіакомпаній і на рівні підготовки для одержання кваліфікаційної оцінки класу пілота викладено в документах: "Видача посвідчень авіаційному персоналу” і частини 1 "Міжнародний комерційний повітряний транспорт. Літаки”, “Експлуатація повітряних суден”, а також у “Правилах аеронавігаційного обслуговування. Підготовка персоналу" (PANS-TRG, Doc 9868), причому останні видання цих документів набули чинності 13 листопада 2014 року.

Впродовж трьох років IКАО розроблялось керівництво 3 підготовки для запобігання потрапляння літака в складні просторові положення й виводу з них, в його розробці брали участь багато груп експертів виробників повітряних суден і тренажерних комплексів імітації польоту, організацій, що представляють інтереси пілотів, навчальних організацій, управлінь 3 розслідування авіаційних подій, а також фахівці 3 вивчення можливостей і обмежень людини, і після закінчення його підготовки воно було спрямовано широкому колу експертів для незалежної оцінки, щоб врахувати думку співтовариства таких експертів.

Ініціатива LOCART дозволила визначити, що підхід до складання подібної програми підготовки повинен бути головним чином орієнтований на виконання трьох чітко визначених цілей/завдань:

а) підвищення обізнаності про потенційні загрози, пов'язані з подіями, умовами або ситуаціями;

б) ефективне запобігання завдяки своєчасній сигналізації про умови, здатні спровокувати складне просторове положення;

в) ефективне й своєчасне відновлення, що означає вивід літака зі складного просторового положення й повернення до безпечних параметрів польоту.

Розробка ефективної програми підготовки типу UPRT і відповідної нормативної основи вимагають застосування інтегрального комплексного підходу, щоб забезпечити стандартизацію на рівні знань і набору професійних навичок у рамках співтовариства пілотів. Ці зусилля по інтеграції повинні містити в собі наступні компоненти підготовки за програмою UPRT:

a) теоретична підготовка - призначена для того, щоб забезпечити оволодіння пілотами знаннями й обізнаністю, необхідними для розуміння загроз безпеки польоту й застосування стратегій зниження ризиків;

б) практична підготовка - підготовка, призначена для того, щоб пілоти оволоділи необхідними наборами професійних навичок для ефективного застосування стратегій iз запобігання складного просторового положення й, коли це необхідно, могли ефективно виводити літак на початково заплановану траєкторію польоту.

Крім того, компонент практичної підготовки підрозділяється на два виразні субкомпоненти, а саме:

а) підготовка на літаку - підготовка претендентів на одержання посвідчення пілота комерційної авіації стосовно до літака (CPL(A)) або посвідчення пілота багаточленного екіпажу (MPL) на придатних до цього легких літаках, причому така підготовка повинна проводитися інструкторами, що мають належну кваліфікацію 3 метою підвищення знань i 
поінформованості тих, хто навчається, і нагромадження ними досвіду відносно порушень керованості літака й потрапляння у складні просторові положення, а також підготовка на предмет того, що стосується ефективного аналізу становища, що створилося, і застосування правильних методів виводу літака з такого становища;

б) підготовка на FSTD - підготовка на тренажерах конкретних типів літаків або на тренажерах загального типу з метою оволодіння необхідними знаннями, досвідом і вмінням застосовувати їх в умовах оптимізації роботи екіпажу в кабіні (CRM) на всіх етапах польоту й у типових умовах відповідних робочих характеристик, функціональності й реакцій літака й систем. Слід ще раз підкреслити, що це навчання повинне проводитися інструкторами, що мають відповідну кваліфікацію.

Кожний компонент цього комплексного підходу повинен бути ретельно розроблений і сформульований для гарантування, що засвоюються належні знання, а також, що досягаються необхідні рівні професійної підготовки пілота.

У таблиці 1 представлений всеосяжний проект програми підготовки типу UPRT, у якому всі рекомендовані елементи такої підготовки розділені на 11 окремих розділів. Наприклад, у першій колонці таблиці зазначені тематичні області й пов'язані 3 ними елементи підготовки, а в другій, третій, четвертій і п'ятій колонках вказуються елементи підготовки і ті платформи, що найбільш відповідають вимогам ефективного навчання.

Примітка. Для забезпечення ефективності підготовки UPRT важливо визнати, щуо тематичні області й відповідні елементи підготовки, опис яких наведено в таблиці $1, \epsilon$ простими засобами формування відповідних професійних навичок, а також можуть допомогти при розробиі відповідних програм підготовки, але це не повинно приводити до застосування формального підходу типу “поставити оиінку” для виконання навчальної програми.

Таблиця 1

Елементи, компоненти й платформи підготовки по програмі UPRT

\begin{tabular}{|c|c|c|c|c|}
\hline Предмети й елементи підготовки & $\begin{array}{l}\text { Теоретична } \\
\text { підготовка }\end{array}$ & $\begin{array}{c}\text { Підготовка } \\
\text { на літаку - } \\
\text { CPL(A)/MPL }\end{array}$ & $\mid \begin{array}{c}\text { Підготовка на } \\
\text { FSTD, що не } \\
\text { стосується } \\
\text { конкретного } \\
\text { типу літака - } \\
\text { (CPL(A)/MPL) }\end{array}$ & $\begin{array}{c}\text { Підготовка } \\
\text { на FSTD } \\
\text { конкретног } \\
\text { о типу } \\
\text { літака }\end{array}$ \\
\hline 1 & 2 & 3 & 4 & 5 \\
\hline \multicolumn{5}{|c|}{ Аеродинаміка } \\
\hline 1) загальні аеродинамічні характеристики & $\cdot$ & $\bullet$ & $\bullet$ & \\
\hline 2) розширені аеродинамічні характеристики & $\cdot$ & $\bullet$ & $\bullet$ & $\bullet$ \\
\hline 3) сертифікація літака й його обмеження & $\cdot$ & $\bullet$ & $\cdot$ & \\
\hline 4) аеродинамічні характеристики (великі й малі висоти) & $\cdot$ & $\bullet$ & $\cdot$ & $\cdot$ \\
\hline 5) льотно-технічні характеристики (великі й малі висоти) & $\cdot$ & $\bullet$ & $\bullet$ & $\cdot$ \\
\hline 6) кут атаки (АОА) і поінформованість про звалювання & $\cdot$ & $\bullet$ & $\cdot$ & $\bullet$ \\
\hline 7) ввімкнення автомату тряски ручки керування & - & $\cdot$ & $\cdot$ & \\
\hline I) ввімкнення автомату віддачі ручки керування & $\bullet$ & $\bullet$ & $\cdot$ & \\
\hline $\begin{array}{l}\text { II) ефекти, пов'язані із числом Маху, що прийнятне для } \\
\text { типу літака }\end{array}$ & • & • & - & \\
\hline 8) стійкість літака & $\cdot$ & $\cdot$ & $\cdot$ & $\cdot$ \\
\hline 9) основні характеристики поверхонь керування & • & $\bullet$ & - & $\bullet$ \\
\hline I) тримери & $\cdot$ & - & & \\
\hline \multicolumn{5}{|l|}{ 10) ефекти обледеніння й забруднення } \\
\hline 11) струмінь повітряного гвинта (якщо застосовне) & - & - & • & \\
\hline \multicolumn{5}{|c|}{ Причини й супутні фактори потрапляння в складне просторове положення } \\
\hline 1) пов'язані з навколишнім середовищем & $\cdot$ & $\cdot$ & & \\
\hline 2) викликані діями пілота & $\cdot$ & $\cdot$ & & \\
\hline 3) механічні відмови & - & - & & \\
\hline
\end{tabular}


1) позитивні/негативні/ перевантаження, які

збільшуються/зменшуються

2) поінформованість про бокові (поперечні)

перевантаження (бокове ковзання)

3) керування перевантаженнями

Керування рівнем тяги

1) взаємозв'язок кінетичної, потенційної й хімічної енергії (потужність)

2) взаємозв'язок між тангажом і потужністю й льотно-

гехнічними характеристиками

3) льотно-технічні характеристики й ефекти, пов'язані 3 незбалансованістю тяги двигунів

Керування траєкторією польоту

1) автоматичні вхідні сигнали для наведення й керування

2) характеристики, що відносяться до конкретного типу

літака

3) автоматичне керування

4) навички ручного керування

\begin{tabular}{c|c|c}
\hline ii & $\bullet$ & \\
\hline & $\bullet$ & \\
\hline & $\bullet$ & \\
\hline
\end{tabular}

\begin{tabular}{l|l}
$\bullet$ & \\
\hline
\end{tabular}

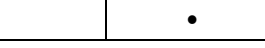

Розпізнавання

1) стосовні до конкретного типу літака приклади показань приладів у процесі наближення й потрапляння в складне

просторове положення

2) тангаж/потужність/крен/нишпорення

3) ефективне відстеження (ефективний моніторинг)

4) системи захисту від звалювання й впливу

5) критерії визначення звалювання й потрапляння в

складне просторове положення

\begin{tabular}{|c|c|c|c|}
\hline$\bullet$ & $\bullet$ & $\bullet$ & \\
\hline & $\bullet$ & $\bullet$ & \\
\hline$\bullet$ & $\bullet$ & $\bullet$ & \\
\hline
\end{tabular}

Методи запобігання складних просторових положень літака й виводу з них

1) своєчасні й адекватні дії

2) вивід літака 3 положення з піднятим носом

(кабрирування)/ без крену

3) вивід літака 3 положення $з$ опущеним носом

(пікірування)/ без крену

4) методи виводу з положення з великим кутом крену

5) узагальнена інформація про методи виводу літака 3

небезпечного положення

\begin{tabular}{|c|c|c|c|c|}
\hline & $\bullet$ & $\bullet$ & $\bullet$ & \\
\hline & $\bullet$ & $\bullet$ & $\bullet$ & $\bullet$ \\
\hline & $\bullet$ & $\bullet$ & $\bullet$ & $\bullet$ \\
\hline & $\bullet$ & $\bullet$ & $\bullet$ & $\bullet$ \\
\hline
\end{tabular}

Несправності систем

1) порушення функціонування системи керування польотом

2) відмова двигунів (часткова або повна)

3) відмова приладів

4) відмова автоматики

5) погіршення захисту електродистанційної системи керування польотом

6) відмова системи захисту від звалювання, включаючи системи сигналізації про обледеніння

1) пікірування по спіралі

2) політ на малій швидкості

3) круті розвороти

4) вивід літака $з$ положення наближення до звалювання

5) вивід зі звалювання, включаючи некоординоване звалювання (що погіршується нишпоренням)

6) вивід зі стану активізації автомату віддачі ручки

керування (якщо застосовується на літаку)

7) вивід літака з положення з піднятим носом

(кабрирування)/з високою швидкістю

\begin{tabular}{|c|c|c|c|}
$\bullet$ & $\bullet$ & $\bullet$ & $\bullet$ \\
\hline$\bullet$ & $\bullet$ & $\bullet$ & $\bullet$ \\
\hline & & $\bullet$ & $\bullet$ \\
\hline$\bullet$ & $\bullet$ & $\bullet$ & $\bullet$ \\
\hline
\end{tabular}

\begin{tabular}{|c|c|c|c|c|}
\hline & $\bullet$ & $\bullet$ & $\bullet$ \\
\hline$\bullet$ & $\bullet$ & $\bullet$ & $\bullet$ \\
\hline$\cdot$ & $\bullet$ & $\bullet$ & $\bullet$ \\
\hline$\bullet$ & $\bullet$ & $\bullet$ & \\
\hline & $\bullet$ & $\bullet$ & $\bullet$ & \\
\hline
\end{tabular}

Спеціалізовані елементи підготовки

\begin{tabular}{|l|l|l|l|}
\hline$\bullet$ & $\bullet$ & $\bullet$ & $\bullet$ \\
\hline$\bullet$ & $\bullet$ & $\bullet$ & \\
\hline$\bullet$ & $\bullet$ & $\bullet$ & \\
\hline$\bullet$ & $\bullet$ & $\bullet$ & \\
\hline$\bullet$ & $\bullet$ & $\bullet$ & \\
\hline$\bullet$ & $\bullet$ & & \\
\hline
\end{tabular}


Закінчення таблиці 1

\begin{tabular}{|c|c|c|c|c|}
\hline $\begin{array}{l}\text { 8) вивід літака } 3 \text { положення з піднятим носом } \\
\text { (кабрирування)/з малою швидкістю }\end{array}$ & $\cdot$ & $\bullet$ & $\bullet$ & \\
\hline $\begin{array}{l}\text { 9) вивід літака з положення з опущеним носом } \\
\text { (пікірування)/з високою швидкістю }\end{array}$ & $\bullet$ & $\bullet$ & $\bullet$ & \\
\hline $\begin{array}{l}\text { 10) вивід літака } 3 \text { положення с опущеним носом } \\
\text { (пікірування)/з малою швидкістю }\end{array}$ & $\cdot$ & $\bullet$ & $\cdot$ & \\
\hline 11) вивід літака з положення з великим кутом крену & $\cdot$ & $\bullet$ & $\bullet$ & \\
\hline $\begin{array}{l}\text { 12) льотна підготовка в умовах, наближених до реальних } \\
\text { (LOFT), або моделювання умов експлуатації, наближених } \\
\text { до реальних (LOS) }\end{array}$ & $\bullet$ & $\bullet$ & & \\
\hline \multicolumn{5}{|l|}{$\begin{aligned} \text { Людський фактор } \\
\end{aligned}$} \\
\hline \multicolumn{5}{|l|}{ 1) ситуаційна поінформованість } \\
\hline I) обробка інформації людиною & $\bullet$ & $\bullet$ & $\bullet$ & $\bullet$ \\
\hline II) неуважність, фіксація уваги, відволікання уваги & $\bullet$ & $\bullet$ & $\bullet$ & $\bullet$ \\
\hline $\begin{array}{l}\text { III) сенсорні ілюзії (візуальні або фізіологічні) і втрата } \\
\text { просторової орієнтації }\end{array}$ & $\cdot$ & $\cdot$ & $\cdot$ & $\bullet$ \\
\hline IV) інтерпретація показань приладів & $\bullet$ & $\bullet$ & $\bullet$ & $\bullet$ \\
\hline \multicolumn{5}{|l|}{ 2) переляк і стресова реакція } \\
\hline I) фізіологічні, психологічні й когнітивні ефекти & $\bullet$ & $\bullet$ & $\bullet$ & $\bullet$ \\
\hline II) стратегії керування & $\bullet$ & $\bullet$ & $\bullet$ & $\bullet$ \\
\hline \multicolumn{5}{|l|}{ 3) контроль фактору загрози й помилок (ТЕМ) } \\
\hline I) структура контролю факторів загрози й помилок (ТЕМ) & $\bullet$ & $\bullet$ & $\bullet$ & $\bullet$ \\
\hline II) активний моніторинг, перевірка & $\bullet$ & $\bullet$ & $\bullet$ & $\bullet$ \\
\hline III) уміння справлятися зі стомлюваністю & $\bullet$ & $\bullet$ & $\bullet$ & $\bullet$ \\
\hline IV) уміння справлятися з робочим навантаженням & $\bullet$ & $\bullet$ & $\bullet$ & $\bullet$ \\
\hline V) Оптимізація роботи екіпажа в кабіні (CRM) & $\bullet$ & $\bullet$ & $\bullet$ & $\bullet$ \\
\hline
\end{tabular}

Володіння навичками виконання штопору для випробувача - факт очевидний. Але для чого потрібно освоювати його льотчикові-винищувачу? Тим більше, що практичне застосування такого маневру - справа досить спірна. У Другій світовій i наступних локальних війнах були випадки його використання для зриву атак супротивника, але при цьому втрачалася тактична ініціатива. У той же час, в умовах ближнього повітряного бою, уникнути перевищення допустимого кута атаки складно як за умовами точності пілотування, так і з тактичних міркувань. Льотчик повинен бути впевнений, що штопор не становить для нього небезпеки та при достатньому запасі висоти завжди можна вивести машину із цього режиму. Якщо такої впевненості немає, навряд чи він зможе використовувати максимальні можливості літака навіть при наявності засобів попередження звалювання.

Крім того, незнання пілотом характерних ознак поведінки машини в штопорі нерідко призводить до того, що маневри 3 інтенсивним кутовим обертанням (типу глибокої спіралі) помилково сприймаються як штопоріння, і звичайна ситуація, у якій літак цілком керований, перетворюється в аварійну.

Вищенаведене підтверджують і сигналограми бортових засобів об'єктивного контролю (ЗОК), що ілюструють статтю М. Раєвського, з яких видно, що після першої віддачі РУ від себе 3 положення $\delta_{\text {в }}=-30^{\circ}$ штопор припинився. Про це говорить і неухильне зростання приладової швидкості, перевантаження, чого на цьому режимі не буває. Навіть при звалюванні на великій швидкості, як показує багаторічний досвід випробувань, літак відразу ж втрачав швидкість до значення, близького до мінімального. У розглянутому ж випадку був керований рух, імовірно глибока спіраль.

Насамперед необхідно пам'ятати, що вихід на режими звалювання й штопора завжди пов'язаний тільки $з$ перевищенням допустимого кута атаки й супроводжується інтенсивним гальмуванням, що пояснюються значною величиною індуктивного опору, а також трансформацією енергії поступального руху в енергію обертання.

Елерони, відхилені проти штопора, роблять зрив більш енергійним. При відхиленому вниз елероні піднімальна сила падає, на ньому підсилюється зрив потоку й цей елерон 
створює гальмування опущеного крила, а на піднятому нагору елероні піднімальна сила росте й тому зрив зменшується. Елерони виконують зворотну дію.

Перш ніж почати будь-які дії по виводу літака з штопора, необхідно:

а) переконатися, що літак дійсно увійшов у штопор;

б) визначити напрямок обертання.

У візуальному польоті напрямок штопора визначається насамперед за характером руху літака відносно землі.

У польоті за приладами штопорний рух літака визначається по авіагоризонту, покажчику повороту, варіометру, висотоміру й курсовим приладам.

Авіагоризонт показує обертання по крену у бік штопора, покажчик повороту сторону обертання, а кулька покажчика ковзання значно переміщується в зовнішню сторону штопора (у бік, протилежний крену). Варіометр і висотомір показують зниження, усі курсові прилади - безперервну зміну курсу.

При навчанні штопору, поряд з показом і навчанням навмисному введенню й виводу зі штопора, необхідно обов'язково показати зрив у штопор з розвороту (віражу) і інших фігур пілотажу як у візуальному польоті, так і в польоті по приладам, імітуючи ненавмисний зрив. Потім відпрацювати шляхом багаторазового повторення дії по попередженню звалювання й переходу літака в штопор.

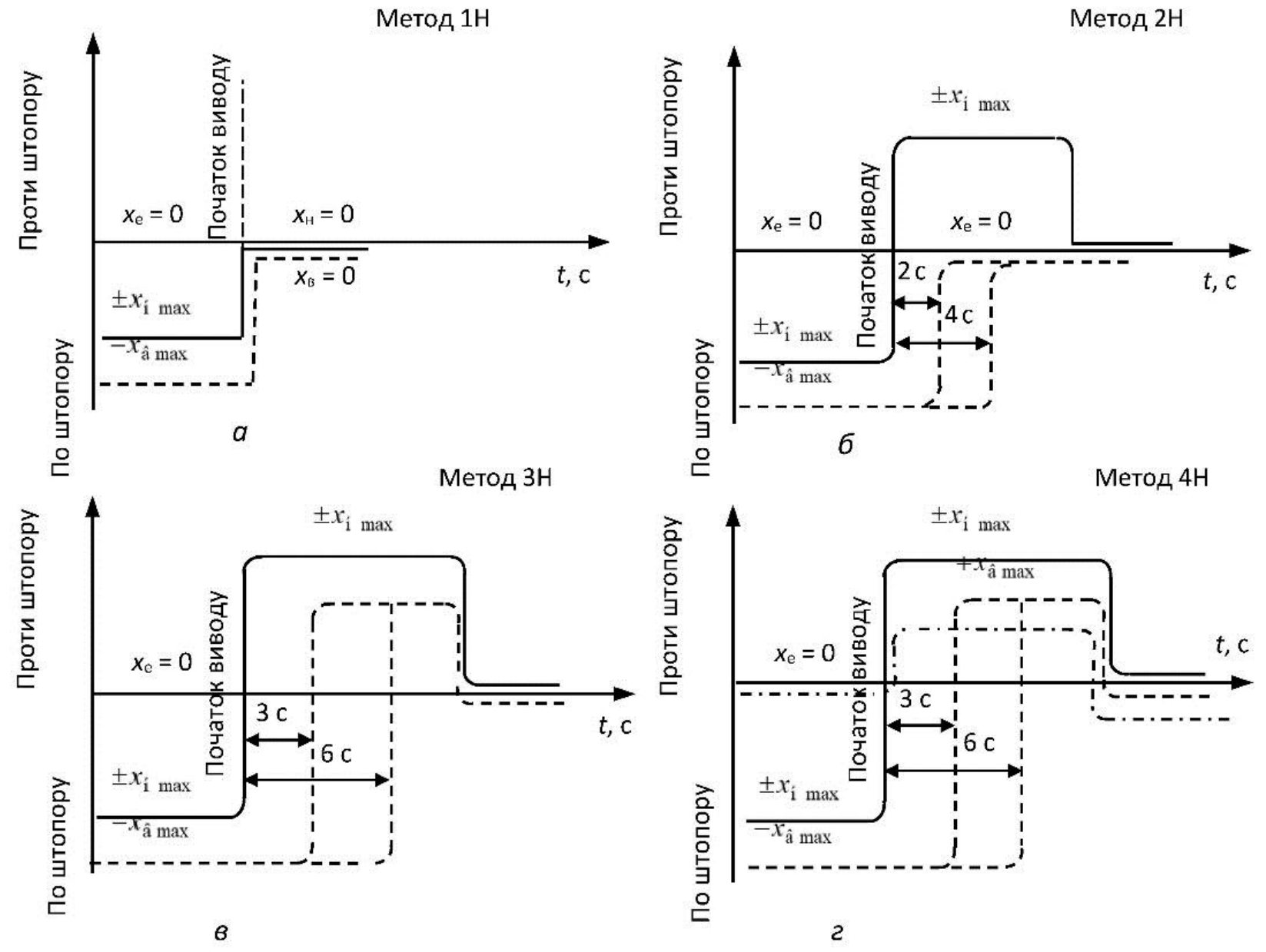

Рис. 2 - методи виведення літака зі штопора

Методи виведення літака зі штопора визначаються можливими випробуваннями (Рисунок 2). Критерієм ефективності методу є найменша втрата висоти за виведення. При правильних діях льотчика на втрату висоти впливають в основному вертикальна швидкість літака у штопорі, час, затрачений на виведення і переведення літака на експлуатаційні кути атаки. Загальна втрата висоти за виведення в горизонтальний політ залежить від того, як у 
штопорі поводив себе двигун. У більшості випадків потрапляння у штопор двигуни переводяться на режим “малого газу” для зменшення ймовірності його самовимкнення. На запуск двигуна (двигунів) у штопорі потрібен певний час, а це додаткова втрата висоти. На втрату висоти суттєво впливає етап, на якому після звалювання почалося виведення зі штопора. Чим раніше льотчик почне виведення зі штопора, тим меншу висоту втратить літак. Підсумовуючи вищесказане, можна викласти загальні дії льотчика по виведенню 3 нормального штопора сучасного маневреного літака:

a) оцінити висоту і прийняти рішення на катапультування, якщо висоти недостатньо для безпечного виведення літака зі штопора;

б) перевести двигун (двигуни) на режим “малого газу”;

в) визначити напрям обертання і відхилити рулі “по штопору” при нейтральних елеронах для покращення умов виведення зі штопора;

г) застосувати один 3 методів виведення зі штопора, але при будь-якому 3 них відхилити руль напрямку енергійно і на максимальний хід для припинення обертання;

д) після припинення обертання поставити рулі нейтрально і перевести літак на пікірування;

е) збільшити режим роботи двигуна (двигунів) до “максималу”. Якщо двигун був вимкнений, то спочатку запустити його;

ж) розігнати літак до безпечної швидкості, проконтролювати відсутність крену і вивести літак у горизонтальний політ. Наявність крену на виведенні - це наявність ковзання, яке призводить до спірального руху. Збільшення перевантаження на виведенні $з$ пікірування за наявності великого ковзання може призвести до звалювання літака.

Конструктори застосовують різноманітні технічні рішення для створення літаків 3 прийнятними характеристиками штопора: інтегральне компонування, застосування профілів крила змінної кривизни, використання активних систем керування. У тих випадках, коли конструктивних рішень недостатньо для покращення характеристик штопора, на літак встановлюють автоматичні пристрої, які створюють перешкоди для льотчика, щоб він не зміг вивести літак на критичні режими.

Основними властивостями авіації, які визначають іiі стан в будь-яких умовах i дозволяють реалізовувати свої бойові можливості та успішне виконання бойових завдань, $\epsilon$ бойова здатність і бойова готовність. Система бойової підготовки (СБП) якраз і спрямована на забезпечення високого рівня бойової здатності і бойової готовності авіаційних частин (підрозділів).

Метою бойової підготовки є досягнення потрібного рівня підготовки та злагодженості органів управління, бойової навченості особового складу, підрозділів забезпечення, що забезпечує реалізацію бойових можливостей озброєння та військової техніки. Мета досягається вирішенням основних задач навчання та виховання особового складу, бойового злагодження органів управління та військ. До СБП авіації ПС ЗС України входять окремі підсистеми [4]:

- теоретична підготовка;

- тренажерна підготовка;

- практична (льотна) підготовка.

При організації бойової підготовки, зокрема ii практичної частини, необхідно забезпечити такий іiі стан, при якому ризики, пов'язані 3 авіаційною діяльністю, що відносяться до експлуатації літаків, знижені до прийнятного рівня й контролюються. Наказом Міністерства оборони України від 15.02.2019 року № 65 на Державний науководослідний інститут випробувань і сертифікації озброєння та військової техніки покладене науково-методичне супроводження розробки та реалізації заходів забезпечення безпеки польотів державної авіації.

3 цією метою запропоновано організувати науково-дослідну роботу за напрямком набуття льотним складом практичних навичок пілотування літака в складних просторових 
положеннях. Для відпрацювання таких навичок доцільно, в першу чергу, провести спеціальну підготовку інструкторського складу (теоретично і практично) до виконання випробувальних польотів на дослідження штопору на учбово-тренувальному літаку Л-39М1.

Висновки. Для впровадження навчання польотам на критичних режимах, інструкторському складу необхідно всебічно дослідити поведінку літака Л-39M1 на звалюванні та штопорі і розробити програму навчання для льотчиків (курсантів). На цьому літаку штопор носить керований характер і являє собою здебільшого психологічний чинник. Перед наданням льотчику (курсанту) допуску на складний або вищий пілотаж ним має бути засвоєна методика вводу у звалювання та штопор та виводу з них учбово-тренувального літака, вивід з яких здійснюється першим або другим методами.

Грамотне пілотування літака по куту атаки - одне 3 найважливіших умов забезпечення безпеки польоту. Якщо все ж таки літак потрапить на вищезазначені критичні режими польоту, то головне для льотчика - зберігати спокій, чітко пам'ятати порядок дій у даній ситуації, і діяти відповідно до інструкції 3 пілотування. Опанування льотчиком (курсантом) методики виводу учбово-тренувального літака зі штопору дає йому в подальшому психологічну впевненість при освоєнні складних маневрів на бойових літаках впритул до їх експлуатаційних обмежень по куту атаки, що, в свою чергу, забезпечить йому перевагу у повітряному бою з літальним апаратом аналогічного типу.

\section{СПИСОК ЛІТЕРАТУРИ}

1. Котик М.Г. Динамика штопора самолёта. / М.Г. Котик. -М.: Машиностроение, 1976. $-328 \mathrm{c}$.

2. Раевский М. Обучать ли штопору? / М. Раевский // Авиация и космонавтика. - 1990. - № 3. - С. 6-7.

3. Щербаков А. Штопору обучать. / А. Щербаков, А. Клумов, А. Горлов // Авиация и космонавтика. - 1991. - № 1. - С. 10-11.

4. Никифоров А.В. Измерение уровня решения задач лётной подготовки при планировании боевой подготовки авиационной части на год [Текст] / А.В. Никифоров // Матеріали міжнародної науково-практичної конференції. - Кіровоград: ДЛАУ, 2009. - C. 211-219.

5. International civil aviation organization. Manual on aeroplane upset prevention and recovery training. First Edition. - 2014. Doc 10011 AN/506.

\section{Кульба Павло Петрович}

науковий співробітник науково-дослідного відділу Державного науково-дослідного інституту випробувань i сертифікації озброєння та військової техніки, Чернігів, Україна https://orcid.org/0000-0002-9256-3884 +38093-150-97-37

\section{Бурсала Олена Олександрівна}

старший науковий співробітник Державного науково-дослідного інституту випробувань і сертифікації озброєння та військової техніки,

Чернігів, Україна

https://orcid.org/0000-0002-1829-1980

$+38067-575-58-69$

\section{Pavlo Kulba}

Researcher of State Scientific Research Institute of Armament and Military Equipment Testing and Certification, Chernihiv, Ukraine https://orcid.org/0000-0002-9256-3884 +38093-150-97-37

\section{Olena Bursala}

Senior Researcher of State Scientific Research Institute of Armament and Military Equipment Testing and Certification, Chernihiv, Ukraine https://orcid.org/0000-0002-1829-1980 $+38067-575-58-69$ 


\section{Лампік Михайло Михайлович}

начальник льотно-методичної Державного науково-дослідного інституту випробувань і сертифікації озброєння та військової техніки, Чернігів, Україна https://orcid.org/0000-0002-4250-056X $+38068-379-86-08$

\section{Mykhailo Lampik}

Chief of Section of State Scientific Research Institute of Armament and Military Equipment Testing and Certification, Chernihiv, Ukraine https://orcid.org/0000-0002-4250-056X $+38068-379-86-08$

\section{THE SUBSTANTIATION OF THE FEASIBILITY AND SAFETY OF PILOTS TRAINING TO PERFORM FLIGHTS IN ORDER TO STUDY THE SPIN OF THE AIRCRAFT AND ITS IMPLEMENTATION IN COMBAT PREPAREDNESS \\ P. Kulba, M. Lampik, O. Bursala}

Over the past five years, eight aviation events have occurred in the Ukrainian Armed Forces: six catastrophes and two accidents, six of them in the Air Force of the Armed Forces of Ukraine, and two in the Army aviation of the Armed Forces of Ukraine. The cause of all aviation events was the human factor. Notwithstanding the measures have been taken by the leadership of the Ministry of Defense of Ukraine and the Armed Forces of Ukraine to ensure safety of flights at an acceptable level to avoid flying accidents and catastrophes due to human factors, preserving the life and health of all categories of aviation specialists and aviation equipment, in the aviation of the Armed Forces of Ukraine aviation events with the death of personnel continue to take place.

In particular, the L-39M1 catastrophe on September 29th, 2017, and the Su-27C on December 15th, 2018 are related to getting the aircraft into a difficult spatial position and insufficient preparation of pilots for flying in such conditions.

Nowadays, the theory of the spin has been thoroughly studied, but this flight mode from time to time causes fatalities, because of inability to timely recognize it.. The article deals with the actual problem of the lack of pilots' flying skills in difficult spatial positions. Recommendations for amendments of the combat training course and conducting the test flights for analising spin on the aircraft L-39MI were provided.

Keywords: difficult spatial positions, stall, spin, combat training, maneuver air combat, flight safety, extreme angle of attack. 